\title{
Loyalty Model Proposal of Travel Agency Customers
}

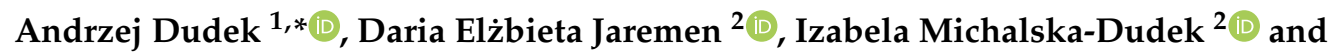 \\ Marek Walesiak ${ }^{1}$ iD \\ 1 Department of Econometrics and Computer Science, Wroclaw University of Economics, \\ 53-345 Wrocław, Poland \\ 2 Department of Marketing and Tourism Management, Wroclaw University of Economics, \\ 53-345 Wrocław, Poland \\ * Correspondence: andrzej.dudek@ue.wroc.pl
}

Received: 7 June 2019; Accepted: 2 July 2019; Published: 5 July 2019

\begin{abstract}
Customer loyalty to a destination and accommodation services constitutes a frequent object of research; however, customer loyalty to travel agencies is rarely analyzed. The presented article is an attempt to fill in this research gap. Its purpose is to construct and verify the model covering the impact of the selected factors on the loyalty level of customers of travel agencies operating in Poland. The conceptualization of the loyalty model of travel agency customers (based on the European path-based EPSI model) proposed in the article was first used to illustrate the existing correlations in customer behavior to analyze and explain the development of the loyalty phenomenon vis-a-vis travel agency customers. The aforementioned assumptions-having applied the structural equation modelling (SEM)-were reflected in the development of the theoretical model of travel agencies customer loyalty, the empirical verification of which $(N=1151)$ allowed us to determine the impacts of selected factors (i.e., the perceived quality of the travel agency's offers, its image and the satisfaction with its service buyers) on the loyalty level of travel agency customers. It has been shown that two major factors have positive impacts on the loyalty of travel agency customers: (i) the perceived quality of travel agency offers, and (ii) its image. Furthermore, the conducted analysis highlights the positive influence of the perceived value of travel agency offers on the loyalty of customers.
\end{abstract}

Keywords: loyalty model; structural equation modelling (SEM); travel agency; package holiday buyer behavior

\section{Introduction}

The notion of loyalty is the subject of interest for representatives of both the scientific and economic fields. The effect of psychological, sociological or economic research covering this phenomenon is identifying its new aspects, along with its further determinants. The research on company (brand) loyalty, approached as part of the decision-making process, was initiated some 100 years ago, i.e., in 1923 [1]. Even though the problem of loyalty is of interest to a growing number of researchers, a universal definition for the term has not yet been provided.

In the literature, three popular approaches to identifying loyalty can be identified, i.e.: loyalty approached as behavior only, as attitudes only, and also jointly as attitudes and behaviors [2]. A "purely" behavioral understanding views loyalty as repeated purchase, the "purely" affective approach refers to emotions (attitudes) manifested by specific behavior in the form of recommendations to other potential customers, and finally, the affective-behavioral approach is related to translating attitudes into behaviors manifested in both repeated purchases as well as through sharing positive opinions or feedback and even co-creating a product. 
The concept of customer loyalty vis-a-vis travel agencies should be understood as customer commitment to the type of purchased tourist offers (holiday packages) and places of their selling/booking (tour operator/travel agent). The result of customer attitude and the intention to purchase tourist services takes the form of a specific behavior, manifested both in repeated purchases and in the espousal of positive opinions about a particular travel agency.

Paraphrasing R. L. Oliver's definition (cf. [3]), the loyalty of travel agency customers may be viewed the deeply rooted belief presented by a customer regarding the purchase of tourist offers (holiday packages), or an ongoing positive attitude towards the preferred categories of tourist offers, which results in repurchasing, performed despite the marketing efforts and influence of competitors, which could result in changing the behavior of tourist service customer [4].

The role of customer loyalty in the operations of travel agencies is unquestionable, and has already been widely covered by scientific research. In addition to the possibility of generating higher revenues and lower costs (e.g., advertising), the major benefit of having loyal customers is reflected in greater stability of the company's operations, higher predictability of its future situation, and finally, in its lasting development opportunities. It can be assumed that customer loyalty represents one of the indispensable conditions facilitating the growth of enterprises. Approaching business sustainability as a company's long-term ability to succeed, expand and develop, the degree of customer loyalty can be referred to as the measure of sustainable business development. In turn, business sustainability, i.e., the adoption of corporate social responsibility by a company, is considered to be the antecedent of customer loyalty, which has already been confirmed in previous, though few, studies conducted predominantly in sectors other than tourism [5-7].

The purpose of this article is to develop and verify a model covering the impact of the selected factors on customer loyalty levels for travel agencies operating in Poland. The conceptualization proposed by the authors regarding the loyalty model of travel agency customers (based on the EPSI path model) was first used to show correlations between various customer behaviors to explain the emergence of loyalty among travel agency customers.

The realization of the aforementioned purpose seeks to fill in the existing research gap, as no in-depth studies covering the factors having an impact on the loyalty of travel agency customers have been conducted so far. The most expanded and advanced EPSI path model and the non-parametric method of multivariate data analysis, SEM, were used as the basis for the research in the article. The conducted research will result in the development of a multivariate process of loyalty development and the acquisition of new knowledge in this area related to important application-oriented values. Identifying factors which determine the loyalty of travel agency customers will make it possible to understand the behavioral specificity of tourist events buyers and to optimize activities carried out by travel agency managers aimed at gaining and maintaining customer loyalty.

Customer loyalty has an impact on the financial results of enterprises by affecting turnover (revenues) from the purchases made by loyal customers and decreasing in operating costs. For this reason, efficient activities focused on supporting the process of developing a loyal customer will enable travel agencies to build a competitive advantage, obtain a guarantee of the purchase of their offers, as well as to minimize the risk of future marketing activities.

The presented research results may also become a useful source of information for the development of operating strategies in the travel agencies market. They identify the potential sources of competitive advantage and the necessary directions for the introduction of modifications in the analyzed area. This knowledge can be used by people involved in marketing, sales and customer service at various levels of management, e.g., by tourism organizers, intermediaries and travel agents for the purposes of effective implementation of activities aiming at both developing and strengthening customer loyalty. 


\section{Conceptual Background}

\subsection{Models of Customer Loyalty}

Attempts to describe loyalty development are presented in the literature from different perspectives, i.e., factors influencing loyalty, its cause and effect mechanisms or various states of the intensity level of the phenomenon.

Some loyalty models point to a simple correlation between several basic variables, whereas others are a description of complex relationships which occur between various phenomena and factors. Some of the models developed by researchers were verified through empirical studies, whereas others were not (more in: [8-10]). Table 1 presents the overview of the variables which characterize the 7 most commonly presented models in the subject literature.

Table 1. Customer loyalty explanatory variables in customer loyalty models.

\begin{tabular}{|c|c|c|c|c|c|c|c|}
\hline Variables & 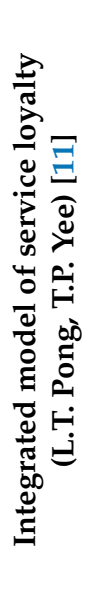 & 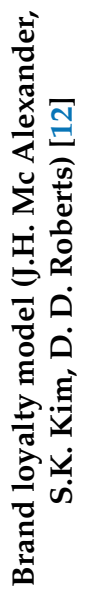 & 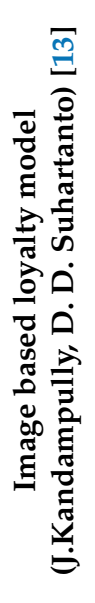 & 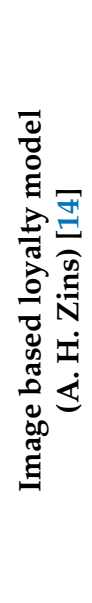 & 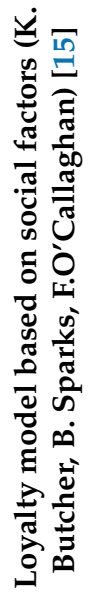 & 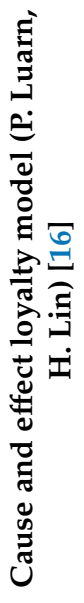 & 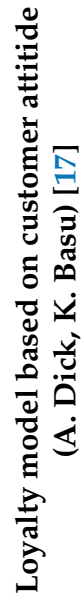 \\
\hline Satisfaction & $\bullet$ & $\bullet$ & $\bullet$ & $\bullet$ & $\bullet$ & $\bullet$ & $\bullet$ \\
\hline Perceived service quality & $\bullet$ & & & & • & & \\
\hline Integration around the brand & & $\bullet$ & & & & & \\
\hline Supplier's image & & & $\bullet$ & $\bullet$ & & & • \\
\hline Perceived offer value & & & & & $\bullet$ & • & \\
\hline $\begin{array}{c}\text { Friendship } \\
\text { Partnership relations }\end{array}$ & & & & & $\bullet$ & & \\
\hline Confidence & & & & & $\bullet$ & $\bullet$ & $\bullet$ \\
\hline Barriers to exit & & & & & $\bullet$ & & $\bullet$ \\
\hline Commitment & & & & & & $\bullet$ & \\
\hline Attitude to the brand & & & & & & & $\bullet$ \\
\hline Brand supporting behavior & & & & & & & • \\
\hline
\end{tabular}

Taking into account the purpose of this article, it is also worth noting the existence of so-called developed path models (SCSB, ACSI, EPSI), which presently constitute the most advanced and also the most inaccurate approach to modelling customer satisfaction and loyalty (more in: [18-20]).

Having adjusted customer loyalty measurement methodology to European markets, the original construction of the presented models was modified and the EPSI model was proposed [21]. A specific market approach is crucial for loyalty phenomenon modelling. For this reason, the industry approach plays a crucial role in loyalty modelling in the tourist market. [10]. 


\subsection{Research Overview of Customer Loyalty in Tourism}

Attempts to recognize the determinants of customer loyalty on the tourist market have, for many years, constituted an important objective of many studies. Table 2 shows the overview of research studies analyzing determinants of customer loyalty on the tourist market.

Table 2. Overview of selected research studies on loyalty in the tourist industry.

\begin{tabular}{|c|c|c|}
\hline Author(s) & $\begin{array}{c}\text { Customer Loyalty } \\
\text { Explanatory Variables }\end{array}$ & Research Subject \\
\hline Pritchard, Howard, 1997 [22] & $\begin{array}{c}\text { Satisfaction } \\
\text { Customer commitment Perception } \\
\text { of service quality }\end{array}$ & Tourist services \\
\hline Petrick, 1999 [23] & $\begin{array}{c}\text { Satisfaction } \\
\text { Perceived service value } \\
\text { Repurchase declaration }\end{array}$ & Golf course \\
\hline $\begin{array}{c}\text { Kandampully, Suhartanto, } 2000 \\
{[13]}\end{array}$ & $\begin{array}{c}\text { Image } \\
\text { Satisfaction }\end{array}$ & Hotel industry \\
\hline Zins, 2001 [14] & $\begin{array}{l}\text { Image } \\
\text { Satisfaction }\end{array}$ & Airlines industry \\
\hline Bowen, Chen, 2001 [24] & Satisfaction & Hospitality industry \\
\hline Lee, Cunningham, 2001 [25] & Service quality & Travel agencies \\
\hline $\begin{array}{l}\text { Petrick, Backman, } \\
2001[26]\end{array}$ & $\begin{array}{l}\text { Repurchase declaration } \\
\text { Satisfaction } \\
\text { Perceived value of the offer }\end{array}$ & Recreational services \\
\hline Yoon, Uysal, 2005 [27] & $\begin{array}{l}\text { Motivation } \\
\text { Satisfaction }\end{array}$ & Destination \\
\hline $\begin{array}{l}\text { Campo Martinez, Yague Guillen, } \\
\qquad 2006 \text { [28] }\end{array}$ & $\begin{array}{l}\text { Price promotion } \\
\text { Perceived quality } \\
\text { Perceived price }\end{array}$ & Travel agencies \\
\hline $\begin{array}{l}\text { Hernández-Lobato, Solis-Radilla, } \\
\text { Moliner-Tena, Sánchez-García, } \\
\text { 2006 [29] }\end{array}$ & Destination Image Satisfaction & Destination \\
\hline $\begin{array}{l}\text { Kim, Han, } \\
2008 \text { [30] }\end{array}$ & $\begin{array}{l}\text { Perceived quality } \\
\text { Perceived value } \\
\text { Relationship quality }\end{array}$ & Restaurant \\
\hline $\begin{array}{l}\text { Campo Martinez, Yague Guillen, } \\
\qquad 2008 \text { [31] }\end{array}$ & $\begin{array}{c}\text { Satisfaction } \\
\text { Perceived Quality } \\
\text { Perceived Price Promotions }\end{array}$ & Travel agencies \\
\hline Mechinda, Serirat, Gulid, 2009 [32] & $\begin{array}{l}\text { Commitment } \\
\text { Perceived value } \\
\text { Satisfaction } \\
\text { Motivation Familiarity }\end{array}$ & Destination \\
\hline Lee, Jeon, Kim, 2011 [33] & $\begin{array}{c}\text { Perceived quality of tourist offers } \\
\text { Customer expectations } \\
\text { Satisfaction } \\
\text { Motivation }\end{array}$ & Travel agencies \\
\hline
\end{tabular}


Table 2. Cont.

\begin{tabular}{|c|c|c|}
\hline Author(s) & $\begin{array}{c}\text { Customer Loyalty } \\
\text { Explanatory Variables }\end{array}$ & Research Subject \\
\hline $\begin{array}{c}\text { Correia Loureiro, Kastenholz, } 2011 \\
\text { [34] }\end{array}$ & $\begin{array}{c}\text { Delight } \\
\text { Satisfaction } \\
\text { Image } \\
\text { Perceived quality }\end{array}$ & Lodging services \\
\hline Seweryn, 2012 [35] & $\begin{array}{c}\text { Satisfaction } \\
\text { Origin of tourists }\end{array}$ & Destination \\
\hline Prayag, Ryan, 2012 [36] & $\begin{array}{l}\text { Destination image } \\
\text { Habits } \\
\text { Commitment } \\
\text { Satisfaction }\end{array}$ & Destination \\
\hline Lai, Vinh, 2013 [37] & $\begin{array}{c}\text { Online promotion } \\
\text { Awareness } \\
\text { Satisfaction }\end{array}$ & Destination \\
\hline Suwunniponth, 2013 [38] & $\begin{array}{l}\text { Service Quality Expectations } \\
\text { Satisfaction }\end{array}$ & Online tourist enterprises \\
\hline Haque, Khan, 2013 [39] & $\begin{array}{l}\text { Destination Image } \\
\text { Perceived Value } \\
\text { Service quality }\end{array}$ & Destination \\
\hline Eid, 2013 [40] & $\begin{array}{c}\text { Customer Perceived Value } \\
\text { Satisfaction } \\
\text { Retention }\end{array}$ & Tourist industry \\
\hline Movafegh, Movafegh, 2013 [41] & $\begin{array}{c}\text { Service quality Demographic } \\
\text { characteristics }\end{array}$ & Tourist industry \\
\hline Jani, Han, 2013 [42] & $\begin{array}{l}\text { Personality } \\
\text { Satisfaction } \\
\text { Image } \\
\text { Ambience }\end{array}$ & Hotel industry \\
\hline Zong, Fu, Cai, Lu, 2014 [43] & $\begin{array}{l}\text { Destination image } \\
\text { (affective, cognitive) }\end{array}$ & Destination \\
\hline $\mathrm{Wu}, 2016[44]$ & $\begin{array}{c}\text { Destination image } \\
\text { Customer travel } \\
\text { Experience } \\
\text { Destination satisfaction }\end{array}$ & Destination \\
\hline Akroush et al., 2016 [45] & $\begin{array}{l}\text { Four dimensions of quality } \\
\text { Brand image }\end{array}$ & Destination \\
\hline Akhoondnejad, 2016 [46] & $\begin{array}{c}\text { Festival authenticity Festival } \\
\text { quality } \\
\text { Value } \\
\text { Satisfaction } \\
\text { Trust }\end{array}$ & Local cultural events \\
\hline $\begin{array}{l}\text { Almeida-Santana, Moreno-Gil, } \\
\qquad 2018 \text { [47] }\end{array}$ & $\begin{array}{c}\text { Cognitive image } \\
\text { Affective image } \\
\text { Overall image } \\
\text { Motivations } \\
\text { Socio-demographic characteristics } \\
\text { Previous behavior } \\
\text { Information source } \\
\text { Intention to visit }\end{array}$ & $\begin{array}{l}\text { Horizontal loyalty to the } \\
\text { destination (HL) }\end{array}$ \\
\hline
\end{tabular}

The research overview of the factors having an impact on customer loyalty on the tourist market indicates that the following categories of variables appear most often among the determinants of loyalty: 
- empathy of the travel services provider, commitment and satisfaction of the customer [22];

- customer satisfaction and contentment as well as the perceived value of the tourist offer [23]

- provider image and the satisfaction of tourist service customer [13,14],

- perceived quality of tourist services, offer costs and leaving costs [25],

- satisfaction and perceived value of the tourist offer [26],

- confidence, satisfaction and perceived value of the offer [16],

- support and quality of customer service [28],

- image $[29,34,43,47]$,

- relationship quality between the supplier and the customer of tourist services, as well as the perceived value of the offer [30],

- satisfaction [27],

- commitment, demographic variables and the perceived value of the offer [32],

- satisfaction and the perceived quality of the offer [33],

- contentment and satisfaction [38],

- image, involvement of tourist service customers and their habits [36],

- promotional activities, awareness and satisfaction of the tourist service customer [37],

- image, perceived value of the offer and quality of tourist services $[39,46]$,

- perceived value of the offer and satisfaction of the tourist service customer [40],

- quality of tourist services, in particular material and security certificates as well as demographic variables describing the tourist service customer [41],

- $\quad$ satisfaction and personality of the tourist service customer, and the image of a travel services provider [42],

- provider image, as well as the experience and satisfaction of tourist service customer [44],

- quality of the offer and the image of the travel service provider [45].

The conducted overview highlights the most frequent variables-apart from satisfactionexplaining customer loyalty. Among them, the following can be cited: quality, image, value, trust, motivation, commitment, price and demographic variables. The loyalty of travel agency customers is a relatively infrequently analyzed problem. For this reason, the purpose of this article is to fill in this research gap through the development and verification of the model, including the selected factors having an impact on the loyalty level of travel agency customers. The analysis covers correlations between the perceived quality of travel agency offers, its image, customer satisfaction with services, and associated loyalty.

\section{Travel Agency Customers in Poland}

Poles are active in tourism. In 2017, the net tourist activity (share of people in the total number of residents participating in at least one trip for tourist purposes per year) in Poland was 59\% (all numbers provided in this paragraph are based on [48]), which means that approximately 6 out of 10 Poles (i.e., 18.9 million) aged 15 and older undertook at least one trip for the purposes of tourism. This figure has been systematically growing by $2-3 \%$ on an annual basis over the last three years. Almost $18 \%$ of Poles (5.8 million) aged 15 and older participated in foreign trips in the 2017. In total, Poles took part in 57.9 million trips, including 45.9 million domestically. Domestic trips were usually organized individually $(88.2 \%)$. Twelve million foreign trips were recorded, including 6.6 million for purely recreational purposes (leisure, recreation, holiday), and the remaining ones being visits to relatives and acquaintances (3.8 million) and business trips (1.1 million). Every fourth foreign trip made by Poles was organized entirely (22.6\%) or partially $(3.2 \%)$ by a travel agency, and approximately one in ten by an employer or other institution. This shows a growing trend in terms of planning and purchasing tourist trips by Poles. It is obvious that trips organized by a travel agency refer primarily to 6.6 million 
typical tourist trips, and thus, it can be estimated that the annual demand for travel agency services comprises some 3.0 million bookings in Poland.

This demand is serviced by approximately 13,100 entities [49], including 4,800 [50] so-called tourism organizers and entrepreneurs which facilitate purchasing the tourist services (which, in general, can be referred to as tour operators). The remaining part are tourist agents, i.e., sellers of service packages organized by tour operators based on contracts concluded with them, and entities assisting clients in booking individual tourist services. The largest suppliers of service packages are Itaka, TUI Poland and Rainbow Tours. The first of these, for many years, has been occupied the top position in travel agency rankings, and has a significant group of permanent, loyal customers.

\section{Empirical Loyalty Analysis}

\subsection{Survey and Sampling Method}

The implementation of the main research goal was based on the results of surveys carried out among travel agency customers. The research was addressed to adult customers who, within the period of the past 10 years, made service purchases at a travel agency in Poland. The survey, with its basic tool being a questionnaire, included 32 questions and the respondent particulars.

The research was conducted as follows:

- partial research, i.e., focused only on a certain group of individuals selected from the entire analyzed population,

- personal interviews based on a questionnaire, carried out by interviewers, and

- non-representative research.

During the first stage of the sample selection, the population was specified, i.e., adult customers who purchased tourist services from a travel agency in Poland in the past 10 years. Due to the impossibility of estimating the sampling frame, non-probability sampling techniques were used in the study, i.e., a sample selection based on the snowball method and the internet selection method. The choice of two ways to fill in the questionnaires was dictated primarily to serve the convenience of the respondents, and was intended to allow them to make an independent choice of the most appropriate form for providing answers, i.e., on paper or online. The aforementioned procedures were implemented simultaneously.

While determining the sample size, both the time and financial possibilities of the conducted research were taken into account, as well as the diversity and knowledge level of the studied population, the personal experiences of the authors, and those of other researchers. Due to the inability to estimate the sampling frame, in the conducted study, non-probability sampling techniques were used, i.e., snowball sampling and an online selection method.

Snowball sampling consists of analyzing an initially selected small group of respondents (customers of travel agencies in Poland), where each member of the group determines the other individuals belonging to the population. The second group was selected by reference. This process, compared to snowball rolling, is continued until the specified sample size is reached. In the opinion surveys, this technique is primarily used in situations where there are no official registers and a good sampling frame is missing.

In turn, the online selection method represents a non-random method for determining the sample composition. Concerns about using non-random sampling techniques refer mainly to the possibility of estimating errors occurring in generalizing regularities observed in the sample over the entire population. The characteristics of the population should be limited to statistical descriptions rather than inferences. The regularities observed in the sample can still be applied to the population which the sample represents; however, albeit attributing the magnitude of error or the probabilities of truthfulness to them.

Ultimately, 1151 respondents were included the research. 


\subsection{Characteristics of the Research Sample}

Among the respondents, there were representatives of both genders. Respondents aged 36-45 constituted the largest age group (over $30 \%$ of indications). The customers with higher and secondary education dominated (a total of over 94\%). Every third respondent had children, and the household usually consisted of 3 people ( $32.86 \%$ indications), 4 people $(25.60 \%$ indications) or 2 people $(24.80 \%$ indications). The largest surveyed group (over $65 \%$ ) consisted of respondents living in cities with populations of between 100,000 and 200,000, as well as 50,000 and 100,000 residents. Half of the respondents assessed their financial situation positively, and none of them evaluated it as being very bad. Detailed characteristics of the sample are presented in Table 3.

Table 3. Characteristics of the research sample $(\mathrm{N}=1151)$.

\begin{tabular}{|c|c|c|}
\hline Respondent Particulars & Categories & $\begin{array}{c}\% \text { of the } \\
\text { Analyzed Sample }\end{array}$ \\
\hline \multirow{2}{*}{ Gender } & Female & 50.12 \\
\hline & Male & 49.88 \\
\hline \multirow{5}{*}{ Age } & $18-25$ & 22.62 \\
\hline & $26-35$ & 21.52 \\
\hline & $36-45$ & 31.83 \\
\hline & $46-60$ & 19.28 \\
\hline & Over 60 & 4.75 \\
\hline \multirow{4}{*}{ Education } & Primary & 0.36 \\
\hline & Vocational & 5.27 \\
\hline & Secondary & 42.78 \\
\hline & Tertiary & 51.59 \\
\hline \multirow{2}{*}{ Minor children in a household } & Yes & 35.59 \\
\hline & No & 64.41 \\
\hline $\begin{array}{l}\text { Average number of all } \\
\text { household members }\end{array}$ & From 1 to $n, n_{\max }=7$ & Mean $=3.01$ \\
\hline \multirow{7}{*}{$\begin{array}{l}\text { Assessment of own } \\
\text { financial standing }\end{array}$} & Village & 33.74 \\
\hline & up to 20,000 residents & 10.85 \\
\hline & from 20 to 50,000 residents & 10.40 \\
\hline & from 50 to 100,000 residents & 17.95 \\
\hline & from 100 to 200,000 residents & 18.43 \\
\hline & from 200 to 500,000 residents & 5.93 \\
\hline & over 500,000 residents & 2.70 \\
\hline \multirow{5}{*}{$\begin{array}{l}\text { Assessment of own } \\
\text { financial standing }\end{array}$} & Very good & 16.06 \\
\hline & Good & 50.31 \\
\hline & Average & 30.61 \\
\hline & Bad & 3.02 \\
\hline & Very bad & - \\
\hline
\end{tabular}

Note. The authors' compilation is based on survey studies covering holiday packages buyers. The surveyed sample indicates the structure of the analyzed adult population (cf. [51]). 


\subsection{The Assumptions of Loyalty Model of Travel agency customers}

Having considered the specificities of the travel agency market, discussed the characteristics of their offers, and provided a description of customer behavior, the European modified path model EPSI was subject to verification; the conducted analysis then covered the following phases:

- conceptualization, over the course of which the theoretical travel agency customer loyalty model was developed, presenting an approach of travel agency customers to understanding loyalty, along with formulating the detailed research hypotheses,

- operationalization, during which operational definitions were assigned to all the concepts and relationships included in the theoretical model,

- empirical verification, i.e., performing an empirical study which covered collecting the empirical data necessary to verify the 7 detailed research hypotheses.

The purpose of the conducted analysis was to determine the impacts of the selected factors (perceived quality of the travel agency offer, its offer value, its image, customer satisfaction with its services) on the loyalty level of travel agency customers. These assumptions were reflected in the development of a conceptual model presenting the relevant date (Figure 1) $[18,52,53]$ ).

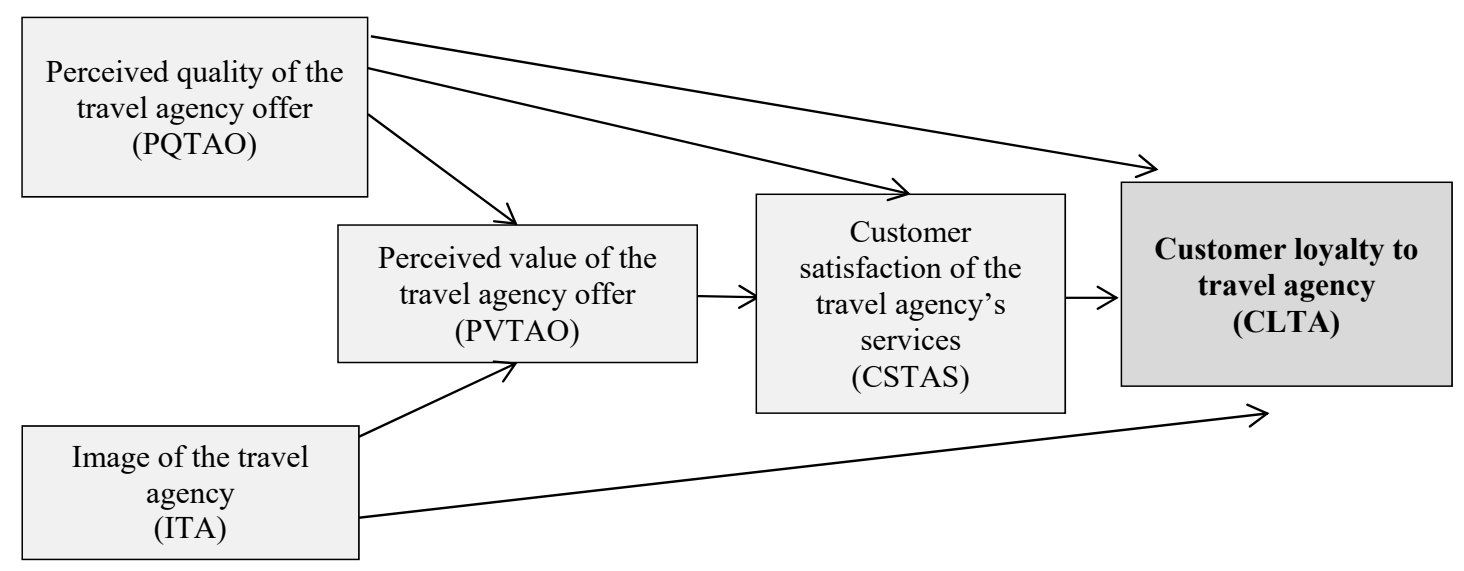

Figure 1. Conceptual model of travel agency customer loyalty.

\subsection{Structural Equation Modelling}

The model was subject to verification by empirical studies. SEM structural modelling was applied in the operationalization of the proposed conceptual model. This choice was due to the nature of the variables defined in the model. Such a complex structure of economic phenomena required the use of more complex models which were capable of reflecting them accurately. It was necessary to include latent (unobservable) variables in the analysis. Including such variables in the model and testing research hypotheses featuring high levels of complexity of correlations between variables was possible thanks to the structural equation modelling (SEM) (cf. [54]).

Structural equation models (SEM) represent a set of statistical procedures and tools which can be defined as the effect of combining confirmatory factor analysis developed mainly in the field of psychology (cf. [55]) and modelling equations of cause-and-effect nature applied in econometrics (multivariate regression and path analysis), aimed at measuring causal correlations in scientific empirical studies.

Structural equation modelling allowed us to verify the theoretical hypotheses formulated based on existing correlations between the particular variables, both in their occurrence and their strength and direction. The extended structure allowed us to identify the causal relationships between four important categories of variables, i.e., endogenous observable, exogenous latent, endogenous latent, and exogenous latent variables [56]. 
The unquestionable advantage of SEM is the possibility of analyzing both direct and indirect correlations. These models allowed us to take into account not only the correlations between latent and observable variables (measurement models), but also the structure of correlations between latent variables. Structural models make it possible to analyze the simultaneous impacts of multiple sources on the dependent variable (cf. $[57,58]$ ). In addition, the variables included in the models can be measured on various scales.

The SEM model consists of two parts: an external model, i.e., a measurement model (for measuring endogenous and exogenous unobservable variables) [43], and the structural equation model (an internal one). The external model uses the factor analysis method which can calculate individual factor loadings having an impact on the latent variable. The internal model, in turn, provides path analyses which make it possible to determine cause-and-effect correlations between variables. In the absence of latent variables, the SEM model is reduced to a multi-equation model, whereas in the absence of causative correlations between variables, the model is reduced to a factor analysis.

Structural equation modelling can be carried out using many statistical packages. For this purpose, the AMOS module of the IBM SPSS statistical package or the Statistica SEPATH module can be applied. In this article, the sem package of the R environment was used for structural equation modelling [59]

\subsection{The Loyalty Model of Travel Agency Customers}

The proposed loyalty model conceptualization of travel agency customers is based on the most advanced European path model (EPSI) and, in the context of loyalty analysis of travel agency customers in Poland, was first implemented to determine mutual correlations of customer behavior and, above all, to identify the impact of selected factors (perceived quality of the travel agency's offer, the value of its offers, its image, and customer satisfaction level with its services) on the loyalty level of travel agency customers. The content of 7 detailed hypotheses, verified over the course of the conducted research, resulted directly from the assumptions made using the EPSI model, which are described in detail in the conceptual model of loyalty of travel agency customers (cf. Figure 1) [18,52,53].

Figure 2 presents the model approach proposed in the operationalization phase, exploring the correlations between the selected variables (described in detail in Table 4) and the loyalty of travel agency customers. The development of a hypothetical SEM model served to verify the following detailed hypotheses:

Hypothesis 1 (H1). The perceived quality of the travel agency offer has a positive impact on the perceived value of its offer.

Hypothesis 2 (H2). The perceived quality of the travel agency offer has a positive impact on customer satisfaction with its services.

Hypothesis 3 (H3). The perceived quality of the travel agency offer has a positive impact on its customer loyalty.

Hypothesis $4 \mathbf{( H 4 ) .}$. The image of the travel agency has a positive impact on the perceived value of its offers.

Hypothesis 5 (H5). The image of the travel agency has a positive impact on customer loyalty.

Hypothesis 6 (H6). The perceived value of the travel agency offer has a positive impact on customer satisfaction with its services.

Hypothesis 7 (H7). The customer satisfaction with the travel agency services has a positive impact on customer loyalty. 
Table 4. Operationalization phase-Latent variables in the theoretical loyalty model of travel agency customers.

\begin{tabular}{|c|c|c|c|c|}
\hline Latent Variables & $\begin{array}{c}\text { Symbol of the Observed } \\
\text { Variables (According to } \\
\text { the Scheme) }\end{array}$ & $\begin{array}{l}\text { Survey Question Addressed to Customers of Travel } \\
\text { Agency Services }\end{array}$ & Categories & $\begin{array}{l}\text { Type of Scale Used to } \\
\text { Measure the } \\
\text { Explanatory Variable }\end{array}$ \\
\hline \multirow{9}{*}{$\begin{array}{l}\text { Perceived quality of } \\
\text { the travel agency } \\
\text { offer (PQTAO) }\end{array}$} & PQTAO1 & How do you rate the overall quality of $X$ travel agency offer? & Q_8: [1] Perfectly, [2] Very good, [3] Good, [4] Average, [5] Poor & Ordinal \\
\hline & PQTAO2 & Did the quality of $X$ travel agency offer meet your expectations? & $\begin{array}{l}\text { Q_9: [1] Definitely yes, [2] Rather yes, [3] It is hard to say, } \\
\text { [4] Rather no, [5] Definitely no }\end{array}$ & Ordinal \\
\hline & PQTAO3 & $\begin{array}{l}\text { Please rate the quality of } X \text { travel agency's offers against to the } \\
\text { quality of competitive offers }\end{array}$ & $\begin{array}{l}\text { Q_10: [1] Definitely better, [2] Better, [3] A little better, } \\
\text { [4] Slightly better, [5] The same as others }\end{array}$ & Ordinal \\
\hline & \multicolumn{2}{|c|}{$\begin{array}{l}\text { PQTAO4 (5 elements): How do you rate the individual elements of X travel agency's offer? } \\
\text { (according to } 5 \text { RATER quality ratings measured in Likert scale*): }\end{array}$} & \multicolumn{2}{|c|}{$\begin{array}{c}\text { (Q_11) ) Q_11_1-5: [1] I totally agree, [2] I agree, [3] I rather agree, [4] I neither agree nor } \\
\text { disagree, [5] I rather disagree, [6] I disagree, [7] I totally disagree }\end{array}$} \\
\hline & PQTAO4A & reliability, dependability $(\mathrm{A})$, & Q_11_1: <1;7> & Ordinal \\
\hline & PQTAO4B & certainty, guarantee (B); & Q_11_2: as above & Ordinal \\
\hline & PQTAO4C & material elements of the service $(C)$, & Q_11_3: as above & Ordinal \\
\hline & PQTAO4D & thoughtfulness, focus on the individual customer, empathy (D), & Q_11_4: as above & Ordinal \\
\hline & PQTAO4E & $\begin{array}{l}\text { willingness to provide support and service at an appropriate } \\
\text { level (E). }\end{array}$ & Q_11_5: as above & Ordinal \\
\hline \multirow{2}{*}{$\begin{array}{l}\text { Perceived value of } \\
\text { the travel agency } \\
\text { offer (PVTAO) }\end{array}$} & PVTAO1 & $\begin{array}{l}\text { Please rate if the benefits of consuming X travel agency's offer } \\
\text { exceeded its costs? }\end{array}$ & $\begin{array}{l}\text { Q_ 12: [1] Definitely yes, [2] Rather yes, [3] It is hard to say, [4] } \\
\text { Rather no, [5] Definitely no }\end{array}$ & Ordinal \\
\hline & PVTAO2 & $\begin{array}{l}\text { How do you rate the price of } X \text { travel agency's offer from the } \\
\text { perspective of the received benefits? }\end{array}$ & $\begin{array}{l}\text { Q_13: [1] Excellent, [2] Very good, [3] Good, [4] Average, } \\
\text { [5] Poor }\end{array}$ & Ordinal \\
\hline \multirow{11}{*}{$\begin{array}{l}\text { Image of the travel } \\
\text { agency (ITA) }\end{array}$} & \multicolumn{2}{|c|}{ Do you agree with the following statements referring to $X$ travel agency? } & \multicolumn{2}{|l|}{ (Q_16) Q_16_1-10 } \\
\hline & ITA1 & $\mathrm{X}$ travel agency is trustworthy? & $\begin{array}{l}\text { Q_16_1: [1] I totally agree, [2] I agree, [3] I rather agree, } \\
\text { [4] I neither agree nor disagree, [5] I rather disagree, } \\
\text { [6] I disagree, [7] I totally disagree }\end{array}$ & Ordinal \\
\hline & ITA2 & $\mathrm{X}$ travel agency has a strong market position? & as above & Ordinal \\
\hline & ITA3 & X travel agency puts customer's needs first? & as above & Ordinal \\
\hline & ITA4 & $\mathrm{X}$ travel agency provides high quality services? & as above & Ordinal \\
\hline & ITA5 & $X$ travel agency offers new products every season & as above & Ordinal \\
\hline & ITA6 & $\mathrm{X}$ travel agency is a modern entity & as above & Ordinal \\
\hline & ITA7 & $\mathrm{X}$ travel agency is reliable & as above & Ordinal \\
\hline & ITA8 & X travel agency's services are attractive & as above & Ordinal \\
\hline & ITA9 & $\mathrm{X}$ travel agency's services are competitive & as above & Ordinal \\
\hline & ITA10 & $X$ travel agency's services are worth their price & as above & Ordinal \\
\hline
\end{tabular}


Table 4. Cont

\begin{tabular}{|c|c|c|c|c|}
\hline Latent Variables & $\begin{array}{l}\text { Symbol of the Observed } \\
\text { Variables (According to } \\
\text { the Scheme) }\end{array}$ & $\begin{array}{c}\text { Survey Question Addressed to Customers of Travel } \\
\text { Agency Services }\end{array}$ & Categories & $\begin{array}{l}\text { Type of Scale Used to } \\
\text { Measure the } \\
\text { Explanatory Variable }\end{array}$ \\
\hline \multirow{2}{*}{$\begin{array}{l}\text { Customer satisfaction } \\
\text { with the travel agency } \\
\text { services (CSTAS) }\end{array}$} & CSTAS1 & $\begin{array}{l}\text { What is your satisfaction level with the quality of } X \text { travel } \\
\text { agency's services? }\end{array}$ & Q_14: [1] I am dissatisfied, [2] I am satisfied, [3] I am delighted & Ordinal \\
\hline & CSTAS2 & $\begin{array}{c}\text { Did the services provided by } X \text { travel agency meet } \\
\text { your expectations? }\end{array}$ & $\begin{array}{c}\text { Q_15: [1] Yes, [2] No, [3] The provision of services exceeded } \\
\text { my expectations }\end{array}$ & Nominal \\
\hline \multirow{3}{*}{$\begin{array}{l}\text { Customer loyalty to } \\
\text { travel } \\
\text { agencies (CLTA) }\end{array}$} & Affective loyalty (ALTAC) & $\begin{array}{l}\text { Would you recommend the services provided by } X \text { travel } \\
\text { agency to your friends? }\end{array}$ & $\begin{array}{l}\text { Q_20: [1] Definitely yes, [2] Probably yes, [3] Maybe, } \\
\text { [4] Probably no, [5] Definitely no }\end{array}$ & Ordinal \\
\hline & \multirow{2}{*}{$\begin{array}{l}\text { Behavior al loyalty } \\
\text { (BLTAC) }\end{array}$} & $\begin{array}{l}\text { Do you intend to use } X \text { travel agency services again in } \\
\text { the future? }\end{array}$ & Q_24: as above & Ordinal \\
\hline & & $\begin{array}{l}\text { How likely is it that you will continue purchasing the services } \\
\text { provided by } X \text { travel agency if you receive a better offer from } \\
\text { one of its competitors? }\end{array}$ & Q_23: $<0 ; 10>$ & Ordinal \\
\hline
\end{tabular}

Note. * This scale was proposed by Rensis Likert in 1932 ([60,61], p. 122). Respondent refers to the category on the ordinal scale, which corresponds to his/her attitude to a given statement. The Likert scale used in the questionnaire is a 7-category scale. 


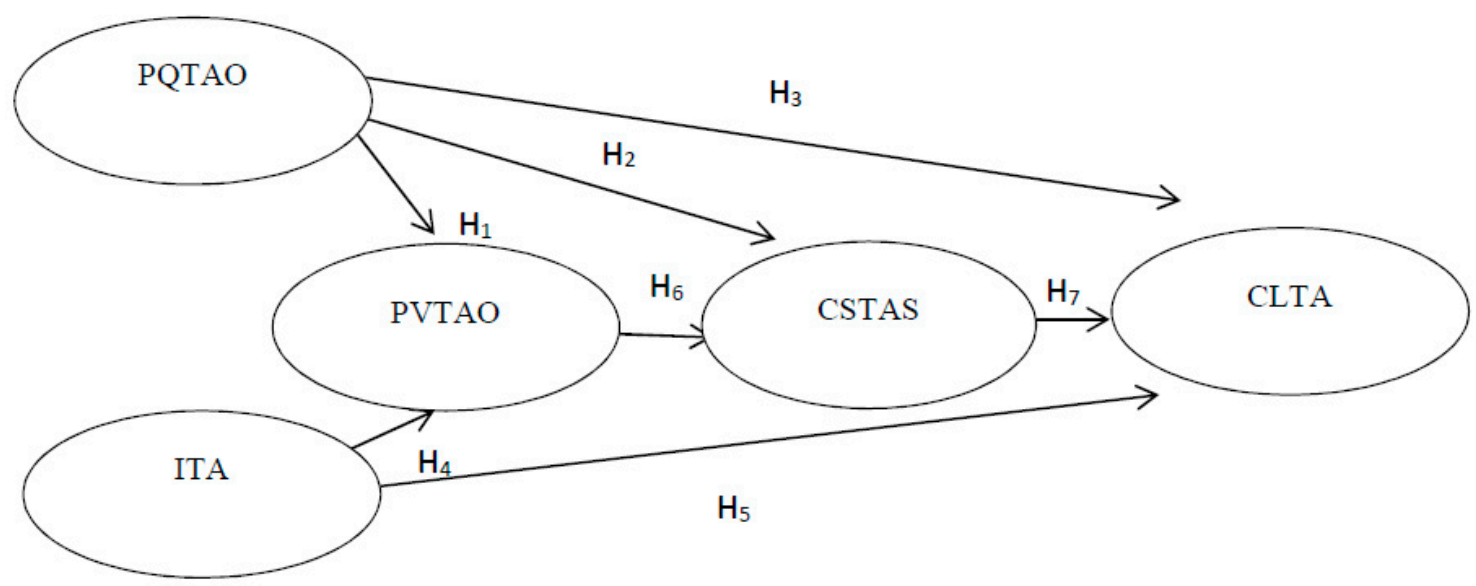

Figure 2. Research operationalization phase-the scheme of hypothetical correlations in the loyalty model of travel agency customers.

The analysis of correlations between the loyalty of travel agency customers and the selected factors was subject to verification through empirical studies carried out based on the data collected in survey studies covering travel agency customers $(\mathrm{N}=1151)$ using structural equation modelling (SEM).

The details of observable variables defining latent, exo- and endo- genous variables and their descriptive statistics are presented in Tables 4 and 5.

Latent (non-measurable) variables represent variables characterized by unobservable realizations in the analyzed sample, and can only be measured indirectly. Mapping correlations between presented exogenous variables $\left(\mathrm{y}_{1}-\mathrm{y}_{4}\right)$ and the endogenous latent variable $\left(\psi_{1}\right)$ or the endogenous observable variable $\left(\mathrm{Y}_{1}\right)$ will constitute an essential element of the model.

The Cronbach's Alpha reliability statistic takes a value greater than 0.9 in the case of each latent variable included in the model; hence the particular sets of observable variables measure the same phenomenon. A Cronbach's Alpha coefficient above 0.7 is most often accepted as a satisfactory value in reliability measurements, and results greater than 0.8 are more than satisfactory.

Table 5. Descriptive statistics of observable variables defining exogenous and endogenous latent variables.

\begin{tabular}{|c|c|c|c|c|c|c|}
\hline Variables (Symbol) & 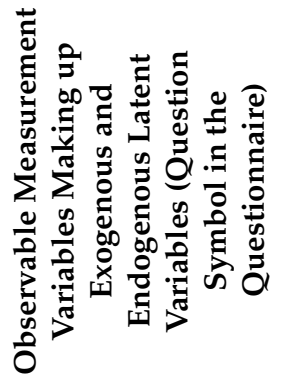 & 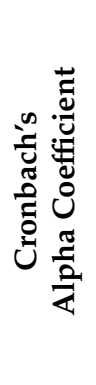 & 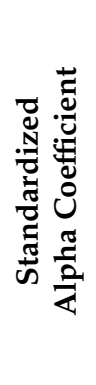 & 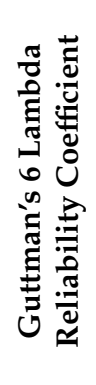 & 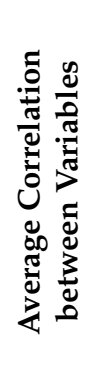 & 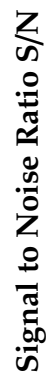 \\
\hline \multirow{8}{*}{$\begin{array}{c}\mathrm{y}_{1} \\
\text { Perceived quality of travel } \\
\text { agency offer } \\
\text { (PQTAO) }\end{array}$} & $\mathrm{x}_{1}\left(\mathrm{Q} \_8\right)$ & 0.93 & 0.95 & 0.96 & 0.40 & 18 \\
\hline & $x_{2}\left(Q \_9\right)$ & 0.93 & 0.95 & 0.96 & 0.41 & 18 \\
\hline & $x_{3}\left(Q \_10\right)$ & 0.93 & 0.95 & 0.96 & 0.42 & 19 \\
\hline & $\mathrm{x}_{4}\left(\mathrm{Q} \_11 \_1\right)$ & 0.93 & 0.95 & 0.96 & 0.41 & 18 \\
\hline & $x_{5}\left(\mathrm{Q} \_11 \_2\right)$ & 0.93 & 0.95 & 0.96 & 0.41 & 18 \\
\hline & $x_{6}\left(Q \_11 \_3\right)$ & 0.93 & 0.95 & 0.96 & 0.41 & 18 \\
\hline & $x_{7}\left(\mathrm{Q} \_11 \_4\right)$ & 0.93 & 0.95 & 0.96 & 0.42 & 18 \\
\hline & $\mathrm{x}_{8}$ (Q_11_5) & 0.93 & 0.95 & 0.96 & 0.40 & 18 \\
\hline \multirow{2}{*}{$\begin{array}{c}\mathrm{y}_{2} \\
\text { Perceived value of travel } \\
\text { agency offer } \\
\text { (PVTAO) }\end{array}$} & X9 (Q_12) & \multirow{2}{*}{$\begin{array}{l}0.93 \\
0.93\end{array}$} & 0.95 & 0.96 & 0.42 & 19 \\
\hline & $x_{10}\left(\mathrm{Q} \_13\right)$ & & 0.95 & 0.96 & 0.40 & 18 \\
\hline
\end{tabular}


Table 5. Cont.

\begin{tabular}{|c|c|c|c|c|c|c|}
\hline Variables (Symbol) & 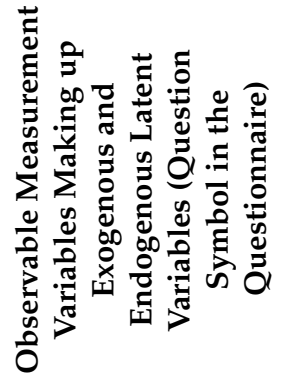 & 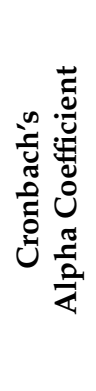 & 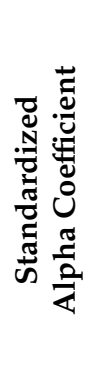 & 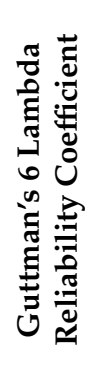 & 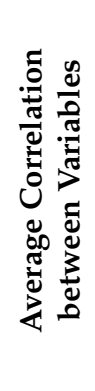 & 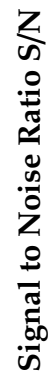 \\
\hline \multirow{10}{*}{$\begin{array}{c}\mathrm{y}_{3} \\
\text { Image of travel agency } \\
\text { (ITA) }\end{array}$} & $\mathrm{x}_{11}$ (Q_16_1) & 0.93 & 0.95 & 0.96 & 0.40 & 18 \\
\hline & $\mathrm{x}_{12}\left(\mathrm{Q} \_16 \_2\right)$ & 0.93 & 0.95 & 0.96 & 0.41 & 18 \\
\hline & $x_{13}$ (Q_16_3) & 0.93 & 0.95 & 0.96 & 0.40 & 18 \\
\hline & $x_{14}\left(\mathrm{Q} \_16 \_4\right)$ & 0.93 & 0.95 & 0.96 & 0.40 & 17 \\
\hline & $x_{15}$ (Q_16_5) & 0.93 & 0.95 & 0.96 & 0.41 & 18 \\
\hline & x16 (Q_16_6) & 0.93 & 0.95 & 0.96 & 0.41 & 18 \\
\hline & $x_{17}\left(\mathrm{Q} \_16 \_7\right)$ & 0.93 & 0.95 & 0.96 & 0.40 & 18 \\
\hline & $x_{18}\left(\mathrm{Q} \_16 \_8\right)$ & 0.93 & 0.95 & 0.96 & 0.40 & 18 \\
\hline & $x_{19}$ (Q_16_9) & 0.93 & 0.95 & 0.96 & 0.40 & 18 \\
\hline & $\mathrm{x}_{20}$ (Q_16_10) & 0.93 & 0.95 & 0.96 & 0.41 & 18 \\
\hline \multirow{2}{*}{$\begin{array}{c}\mathrm{y}_{4} \\
\text { Customer satisfaction with } \\
\text { travel agency services } \\
\text { (CSTAS) }\end{array}$} & $\mathrm{x}_{21}\left(\mathrm{Q} \_14\right)$ & \multirow{2}{*}{$\begin{array}{l}0.93 \\
0.94\end{array}$} & 0.95 & 0.96 & 0.42 & 19 \\
\hline & x22 (Q_15) & & 0.95 & 0.96 & 0.44 & 21 \\
\hline \multirow{3}{*}{$\begin{array}{c}\psi_{1} \\
\text { Customer loyalty to travel } \\
\text { agency } \\
\text { (CLTA) }\end{array}$} & $\mathrm{Y}_{1}\left(\mathrm{Q} \_20\right)$ & 0.93 & 0.95 & 0.96 & 0.41 & 18 \\
\hline & $\mathrm{Y}_{2}\left(\mathrm{Q} \_24\right)$ & 0.93 & 0.95 & 0.96 & 0.41 & 18 \\
\hline & $\mathrm{Y}_{3}\left(\mathrm{Q} \_23\right)$ & 0.94 & 0.95 & 0.96 & 0.42 & 19 \\
\hline
\end{tabular}

Note. Authors' compilation based on survey studies and the calculations performed using the sem package of the R environment.

\subsection{Empirical Results}

Figure 3 presents the basic tool used for structural modelling; a path diagram shows graphic the causative correlations between the particular variables. In the diagram, the explicit variables are placed in frames, latent variables in ellipses, and residual variables are not enclosed in any shape. The correlations between the variables included in the model are marked by arrows, the arrowhead of which indicates the resulting variable. In the case of residual variables, the arrow points to an observable variable which is burdened with error.

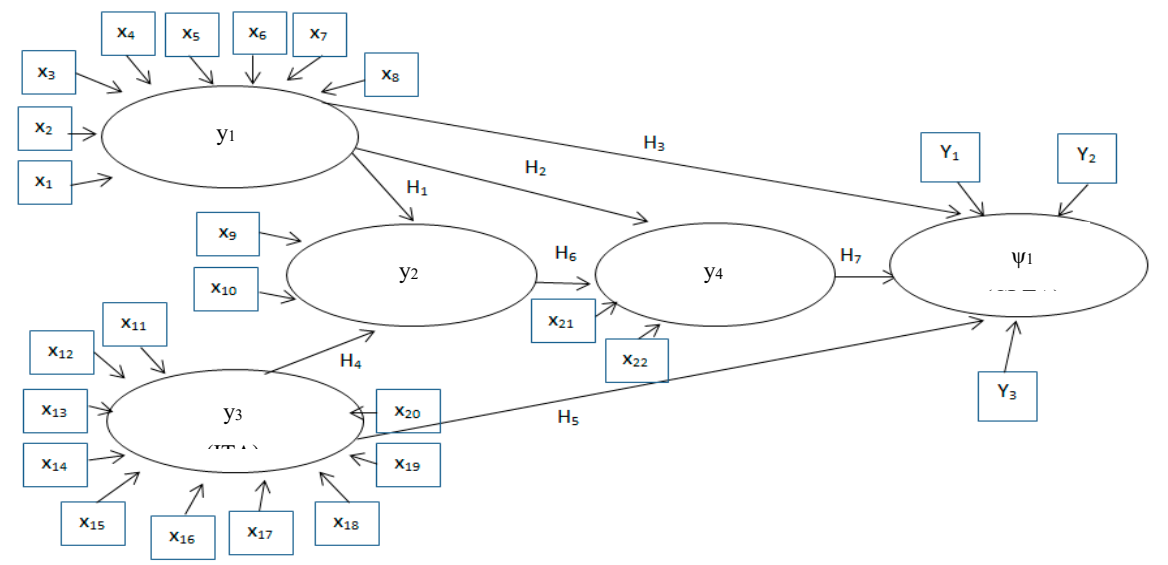

Figure 3. Path diagram of the structural equation loyalty model of travel agency customers. 
$\psi_{1}$-latent endogenous variable, i.e., customer loyalty to travel agencies (CLTA),

$\mathrm{Y}_{1}-\mathrm{Y}_{3}$ - explicit endogenous variables (measurement variables for latent endogenous variable $\psi 1$ ),

$\mathrm{y}_{1}-\mathrm{y}_{4}$-latent exogenous variables:

$\mathrm{y}_{1}$ - perceived quality of the travel agency offer (PQTAO),

$\mathrm{y}_{2}$ - perceived value of the travel agency offer (PVTAO),

$\mathrm{y}_{3}$-image of the travel agency (ITA),

$\mathrm{y}_{4}$-customer satisfaction with the travel agency's services (CSTAS),

$\mathrm{x}_{1}-\mathrm{x}_{22}$ - explicit exogenous variables, measurement variables for the latent exogenous variables.

Tables 6 and 7 present estimation results for the external and internal model, as well as for the model fit measures. Based on these data, the accuracy level of selecting indicators for the model can be assessed. In the course of estimation, the $Y_{3}$ variable turned out to be statistically irrelevant and was removed from the model.

Table 6. The estimated parameters of confirmatory factor analysis for the loyalty model of travel agency customers.

\begin{tabular}{|c|c|c|}
\hline Correlation & Parameters (Factor Loadings) & Parameter Evaluation \\
\hline $\mathrm{x}_{1} \leftarrow \mathrm{y}_{1}$ & $\alpha_{1}$ & 0.56293209 \\
\hline $\mathrm{x}_{2} \leftarrow \mathrm{y}_{1}$ & $\alpha_{2}$ & 0.42240908 \\
\hline $\mathrm{x}_{3} \leftarrow \mathrm{y}_{1}$ & $\alpha_{3}$ & 0.63461933 \\
\hline $\mathrm{x}_{4} \leftarrow \mathrm{y}_{1}$ & $\alpha_{4}$ & 0.68537168 \\
\hline $\mathrm{x}_{5} \leftarrow \mathrm{y}_{1}$ & $\alpha_{5}$ & 0.87324079 \\
\hline $\mathrm{x}_{6} \leftarrow \mathrm{y}_{1}$ & $\alpha_{6}$ & 0.98780418 \\
\hline $\mathrm{x}_{7} \leftarrow \mathrm{y}_{1}$ & $\alpha_{7}$ & 0.89928411 \\
\hline $\mathrm{x}_{8} \leftarrow \mathrm{y}_{1}$ & $\alpha_{8}$ & 0.72743137 \\
\hline $\mathrm{x}_{9} \leftarrow \mathrm{y}_{2}$ & $\alpha_{9}$ & 0.60591996 \\
\hline $\mathrm{x}_{10} \leftarrow \mathrm{y}_{2}$ & $\alpha_{10}$ & 0.85548678 \\
\hline $\mathrm{x}_{11} \leftarrow \mathrm{y}_{3}$ & $\alpha_{11}$ & 0.57343005 \\
\hline $\mathrm{x}_{12} \leftarrow \mathrm{y}_{3}$ & $\alpha_{12}$ & 0.88268766 \\
\hline $\mathrm{x}_{13} \leftarrow \mathrm{y}_{3}$ & $\alpha_{13}$ & 0.83373839 \\
\hline $\mathrm{x}_{14} \leftarrow \mathrm{y}_{3}$ & $\alpha_{14}$ & 0.82327125 \\
\hline $\mathrm{x}_{15} \leftarrow \mathrm{y}_{3}$ & $\alpha_{15}$ & 0.70995634 \\
\hline $\mathrm{x}_{16} \leftarrow \mathrm{y}_{3}$ & $\alpha_{16}$ & 0.84713269 \\
\hline $\mathrm{x}_{17} \leftarrow \mathrm{y}_{3}$ & $\alpha_{17}$ & 0.73508957 \\
\hline $\mathrm{x}_{18} \leftarrow \mathrm{y}_{3}$ & $\alpha_{18}$ & 0.78833315 \\
\hline $\mathrm{x}_{19} \leftarrow \mathrm{y}_{3}$ & $\alpha_{19}$ & 0.87301455 \\
\hline $\mathrm{x}_{20} \leftarrow \mathrm{y}_{3}$ & $\alpha_{20}$ & 0.81113875 \\
\hline $\mathrm{x}_{21} \leftarrow \mathrm{y}_{4}$ & $\alpha_{21}$ & 1.29738599 \\
\hline $\mathrm{x}_{22} \leftarrow \mathrm{y}_{4}$ & $\alpha_{22}$ & 0.02868363 \\
\hline $\mathrm{Y}_{1} \leftarrow \Psi_{1}$ & $\alpha_{23}$ & 0.78325638 \\
\hline$Y_{3} \leftarrow \Psi_{1}$ & $\alpha_{24}$ & -1.45003985 \\
\hline$Y_{2} \leftarrow \Psi_{1}$ & $\alpha_{25}$ & 0.71235723 \\
\hline
\end{tabular}

Note. Authors' compilation based on survey studies and the calculations performed using the sem package of the $R$ environment. $\alpha_{1-25}$-factor loadings determining the correlation strength between latent and explicit variables. 
Table 7. The estimated parameters of an internal model for the loyalty model of travel agency customers.

\begin{tabular}{cccccc}
\hline Correlation & Parameters & Estimate & $\begin{array}{c}\text { Standard } \\
\text { Error }\end{array}$ & $p$-Value & $\begin{array}{c}\text { Conclusions (Verification } \\
\text { of Detailed Hypotheses) }\end{array}$ \\
\hline $\mathrm{H}_{1}: \mathrm{y}_{1} \leftarrow \mathrm{y}_{2}$ & $\beta_{1}$ & 0.70728707 & 0.023 & 0 & Hypothesis confirmed \\
\hline $\mathrm{y}_{1} \leftarrow \mathrm{y}_{3}$ & $\beta_{2}$ & 0.77557835 & 0.015 & 0 & Demonstrated correlation \\
\hline $\mathrm{H}_{2}: \mathrm{y}_{1} \leftarrow \mathrm{y}_{4}$ & $\beta_{3}$ & -0.13269856 & 0.217 & 0 & Hypothesis rejected \\
\hline $\mathrm{H}_{3}: \mathrm{y}_{1} \leftarrow \Psi_{1}$ & $\beta_{4}$ & 0.77237314 & 0.021 & 0 & Hypothesis confirmed \\
\hline $\mathrm{H}_{4}: \mathrm{y}_{2} \leftarrow \mathrm{y}_{3}$ & $\beta_{5}$ & 0.76284150 & 0.021 & 0 & Hypothesis confirmed \\
\hline $\mathrm{H}_{6}: \mathrm{y}_{2} \leftarrow \mathrm{y}_{4}$ & $\beta_{6}$ & -0.16463965 & 0.269 & 0 & Hypothesis rejected \\
\hline $\mathrm{y}_{3} \leftarrow \mathrm{y}_{4}$ & $\beta_{8}$ & -0.17591397 & 0.287 & 0 & - \\
\hline $\mathrm{H}_{5}: \mathrm{y}_{3} \leftarrow \mathrm{Y}_{1}$ & $\beta_{9}$ & 0.82094704 & 0.018 & 0 & Hypothesis confirmed \\
\hline $\mathrm{H}_{7}: \mathrm{y}_{4} \leftarrow \Psi_{1}$ & $\beta_{10}$ & -0.17672338 & 0.289 & 0 & Hypothesis rejected \\
\hline $\mathrm{N}_{2} \mathrm{~A}_{\mathrm{A}}$ &
\end{tabular}

Note. Authors' compilation based on survey studies and the calculations performed using the sem package of the R environment. $\beta_{1-10}$ parameters-correlations representing the impact of exogenous latent variables on the endogenous latent variable.

The main conclusion resulting from the present research was that the conceptual model requires some modification (Figure 4).

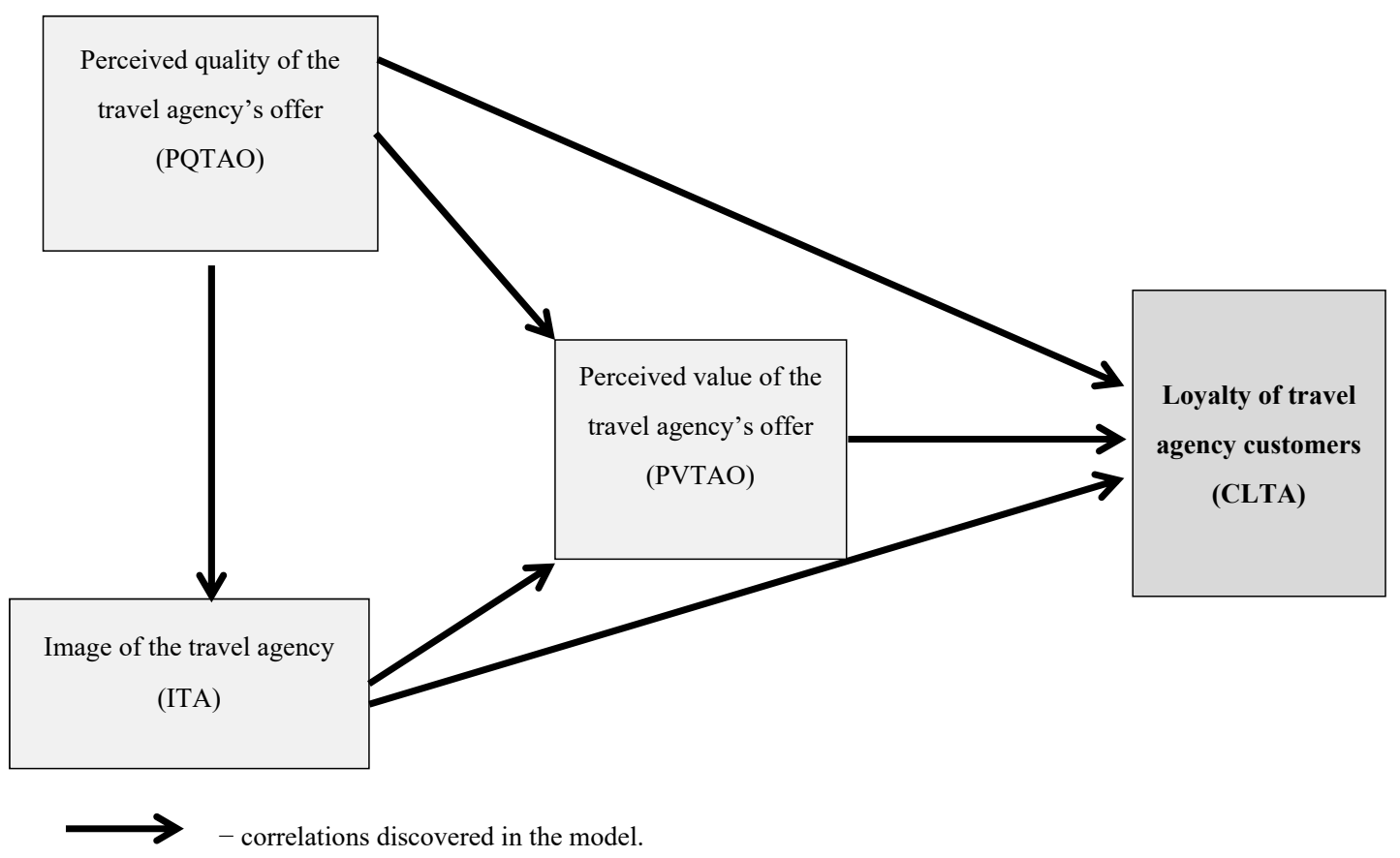

Figure 4. Modified conceptual loyalty model of travel agency customers (based on survey studies and the calculation performed using the sem package of the R environment).

Based on the loyalty model of travel agency customers in Poland:

- the correctness of the four detailed hypotheses was confirmed: $\mathrm{H}_{1}$ (the perceived quality of the travel agency's offer has a positive impact on the perceived value of its offer), $\mathrm{H}_{3}$ (the perceived quality of the travel agency offer has a positive impact on customers loyalty to its services), $\mathrm{H}_{4}$ (the image of the travel agency has a positive impact on the perceived value of its offer) and $\mathrm{H}_{5}$ (the image of the travel agency has positive impact on customer loyalty to its services);

- three detailed hypotheses were rejected: $\mathrm{H}_{2}$ (the perceived quality of the travel agency offer has a positive impact on customer satisfaction with its services), $\mathrm{H}_{6}$ (the perceived value of the travel 
agency offer has a positive impact on customer satisfaction with its services) and $\mathrm{H}_{7}$ (customer satisfaction with the travel agency's services has a positive impact on loyalty to its services);

- it was confirmed that the perceived value of the travel agency's offer $\left(y_{2}\right)$ has a positive impact on the level of global customer loyalty, and that the perceived quality of the travel agency's offer $\left(\mathrm{y}_{1}\right)$ has a significantly positive impact on its image $\left(\mathrm{y}_{3}\right)$.

The conducted estimation and model verification allowed us to formulate general conclusions, i.e., customer loyalty to travel agencies depends on the perceived quality and value of the travel agency's offer, as well as their image.

The final stage of structural modelling consisted of verification of the estimated model regarding its fit degree and the significance of its parameter. The degree of SEM model fit was assessed using many measures based on comparing the estimated model with the base model (Table 8).

Table 8. The statistics of individual models' fit to the actual data.

\begin{tabular}{cc}
\hline Coefficient Name & Values for the Loyalty Model of Travel Agency Customers \\
\hline Chi-square statistic & 1936.292 \\
\hline Jöreskog GFI & 0.8664 \\
\hline Jöreskog AGFI & 0.8362 \\
\hline Steiger-Lind RMSEA & 0.0740 \\
\hline Bentler-Bonett normed fit index (NFI) & 0.8746 \\
\hline Bollen's incremental fit index (IFI) & 0.8899 \\
\hline
\end{tabular}

Note. Authors' compilation based on survey studies and the calculation performed using the sem package of the $\mathrm{R}$ environment). Df $=265$.

Based on a literature overview, an assumption was made about the appropriate quality of the SEM model, i.e., it had to meet the following conditions: the discussed correlation subject to verification had to be substantively correct, all parameters were important and took positive values, Cronbach's Alpha measures for each variable took values lower than 0.7, RMSEA measure took values higher than 0.06 , and IFI, GFI and AGFI were not less than 0.9.

The structural model presented above is characterized by acceptable quality, whereas the fit measures allowed us to conclude that the model accurately reflected the correlations represented by the data, and could serve in the formulation of final conclusions and in the construction of an empirical loyalty model of travel agency customers in Poland.

\section{Discussion and Conclusions}

\subsection{Discussion}

A literature overview confirmed that the research into antecedents is not a novelty, and has been intensively discussed since the 1990s. Table 2 lists only 24 selected examples of previous studies of this type, and obviously does not cover all the existing ones. Tourist loyalty to destinations and accommodation (mainly hotels) are analyzed most frequently. Although searching the scientific literature for information relevant to the research problem was mainly focused on identifying and analyzing previous studies covering travel agency loyalty, the authors came across only four such studies $[25,28,31,33]$. It is, therefore, a research area which has not been fully explored, and one which requires further scientific investigation, even more so as the discoveries made by various authors regarding the variables determining loyalty are partly contradictory, as discussed below.

When comparing the results of the research carried out by the authors of the presented article against the results of previous studies, it should be noted that they remain consistent in terms of the significant and positive impact of the perceived quality of travel agencies' offers on the loyalty of their customers (Table 9). The convergence of the obtained results referred to both the direct and indirect 
(through the perceived value of their offer) impacts of quality on customer loyalty. Studies have also shown a positive and direct correlation between the perceived value of the offer and the loyalty of travel agency customers. This correlation, however, has not been the subject of previous studies in the area of loyalty of travel agency customers. Campo and Yagüe $[28,31]$ showed only an indirect relationship between loyalty and price promotions, and also the perceived offer price, and a direct one between the latter and customer satisfaction, as revealed both in the case of tour operators [31] and tourist agents [28]. In turn, the positively verified (in this study) correlation between the travel agency image and the loyalty of its customers was presented in earlier studies, primarily in the research on tourist loyalty to a tourist destination. Researchers analyzing the loyalty of travel agency customers did not take this into account in their scientific investigations.

Table 9. The antecedents of the loyalty of travel agency customers in both current and previous research.

\begin{tabular}{cccccc}
\hline Antecedent & $\begin{array}{c}\text { Current } \\
\text { Study }\end{array}$ & $\begin{array}{c}\text { Lee, Cunningham, } \\
\text { 2001 [25] }\end{array}$ & $\begin{array}{c}\text { Campo, Yagüe, } \\
\text { 2006 [28] }\end{array}$ & $\begin{array}{c}\text { Campo, Yagüe, } \\
\text { 2008 [31] }\end{array}$ & $\begin{array}{c}\text { Lee, Jeon, Kim, } \\
\text { 2011 [33] }\end{array}$ \\
\hline $\begin{array}{c}\text { Perceived quality of the } \\
\text { travel agency's offer }\end{array}$ & + & + & + & + & + \\
\hline Image of the travel agency & + & not analyzed (n.a.) & n.a. & n.a. & n.a. \\
\hline $\begin{array}{c}\text { Perceived value of the travel } \\
\text { agency's offer }\end{array}$ & + & n.a. & n.a. & n.a. & n.a. \\
\hline $\begin{array}{c}\text { Customer satisfaction with } \\
\text { the travel agency's services }\end{array}$ & - & n.a. & n.a. & n.a. & + \\
\hline Others & no & no & $\begin{array}{c}\text { yes (perceived } \\
\text { price, price } \\
\text { promotions) }\end{array}$ & $\begin{array}{c}\text { yes (perceived } \\
\text { price, price } \\
\text { promotions) }\end{array}$ & $\begin{array}{c}\text { yes (customer } \\
\text { expectations, } \\
\text { motivations) }\end{array}$ \\
\hline
\end{tabular}

However, the discrepancy between the results of current and previous studies occurs in the case of satisfaction as the antecedent of loyalty. The analysis presented in this article did not show such a correlation, whereas Lee, Jeon and Kim [33] confirmed a direct relationship between the satisfaction of travel agency customers and their loyalty. The similarly strong dependence between satisfaction and customer commitment to the service provider or the brand was found in research on loyalty analysis and its factors in the case of a tourist destinations (e.g., [38,45,62]), as well as among other categories of tourist products, e.g., hospitality services e.g., [13,42] and air carrier services (e.g., [14]). The absence of correlations between the satisfaction and loyalty of travel agency customers surprised the authors of the article, all the more so as in each of the models referred to in the article (see Table 1), satisfaction was presented as the variable explaining loyalty. In the literature, satisfaction is recognized as being either quality-based or price-based [63]. So far, many researchers, regardless of the type of analyzed tourist activity $[22,24,26,34,40,42,47]$, or regarding the economic sector in general (e.g., [3,64,65]), identified a direct correlation between satisfaction and loyalty. For this reason, the authors of the presented article approached this correlation as being obvious, and should have also verified it positively in the case of travel agencies. However, this did not happen. Excluding the conceptual error of the research, the reasons were sought by the authors in two sources: in the nature of satisfaction, and also, in the object of travel agency activities and related customer expectations. Firstly, it should be noted that satisfaction is definitely a more subjective and more difficult to measure category than the, for example, quality or value. Secondly, the specificity of travel agency activities consists of combining various tourist services into packages and selling them. From the customer's perspective, travel agency service involves the stage of travel planning and making purchase decisions. The satisfaction achieved at this stage represents only a small part of their satisfaction with the trip itself, and with meeting expectations and tourist needs. In the perception of customers, travel agencies can have a significantly smaller impact on their total satisfaction than service providers and tourist destinations. It should also be noted that this impact is only an indirect one, resulting from the decisions of service providers in the process of packaging them. Therefore, the satisfaction of travel agency customers is not only 
influenced by the service received in a travel agency (e.g., a nice salesperson offering service packages and capable of providing good advice), but is further developed during a tourist's stay in the tourist destination, and as a result of his/her use of various tourist services (e.g., accommodation, catering, recreation or transport). Service providers or the so-called destination services are, to a much greater extent, responsible for it than the creator and/or the seller of their package. However, travel agency service may be perceived by its customers as a kind of technical necessity facilitating the customer's choice of a tourist package and its purchase. In the course of the purchase decision-making process, hard arguments, i.e., measurable, comparable quality parameters and measurable benefits, including both value and price of the service package, count more than the satisfaction from previous trips. Maybe for this reason, in the presented study, the relationship between the offer quality and value and the loyalty was detected, whereas no relationship was found between the satisfaction and loyalty. Nevertheless, the analysis of the research results clearly indicated these new directions:

- firstly, studies deepening the understanding of the absence of correlation between the satisfaction and loyalty of travel agency customers allow researchers to develop new approaches to defining the satisfaction essence of travel agency customers

- secondly, comparative studies of loyalty antecedents in the case of different categories of tourist products make it possible to eliminate the randomness of the results presented in this study

- thirdly, the specificity of the findings may also be related to the nationality of the respondents (the presented study covered Poles only); therefore, it would be worth taking a closer look at the impact of cultural differences on the loyalty of travel agency customers.

The presented observations confirm that the most important determinants of loyalty development by the customers for travel agency services are the following: perceived quality of the travel agency's offers, its image and evaluation of the value its offers, i.e., a critical analysis performed by customers, as well as the calculation of both benefits received and costs incurred.

The findings can support travel agencies in better understanding traveler behavior and planning more effective marketing activities. Regarding the possibilities for developing and strengthening the loyalty of travel agency customers, in addition to typical loyalty activities (for example: clubs and regular customer or loyalty cards, additional services at a reduced fee or no fee, bonuses, gadgets, competitions and lotteries, individualized direct communication, distribution of journals, magazines and bulletins, informational and educational initiatives, organizing events for selected customers, the availability of modern solutions increasing the availability of tourist services, e.g. providing online services, Internet access to certain company resources, offering special mobile applications or computer programs, social media, advergaming), the following are also important: due care and continuous improvement of both the quality and value of tourist offers, as well as constructing the image of a travel agency. The aforementioned variables significantly influence customer loyalty. For this reason, the respective conclusion addressed to people managing travel agencies may be expressed in the suggestion that all actions aimed at improving the company image, as well as improving or maintaining a high quality of offers and their value for customers, should result in strengthening customer loyalty. The presented knowledge can be used by people involved in marketing, sales and customer service at various levels of management, e.g., tour operators or tourist agents, for the successful implementation of marketing activities aimed at developing and strengthening the loyalty of their customers.

The literature query, within the area of interest for the authors of the presented article, also revealed two other important research areas related to loyalty in tourism to be further explored in the future: (i) the determinants of customer loyalty of online travel agencies (cf. $[66,67])$, and (ii) a very interesting, so far unpublished and, above all, adequate for the scientific problems covered by the Sustainability scientific journal research direction, namely the study of correlations between travel agency sustainability, its image and customer loyalty (cf. [63]). 


\subsection{Conclusions}

The conducted research procedure resulted in reducing the list of diagnostic variables used for measuring $\psi_{1}$, whereas after introducing certain modifications, the proposed conceptualization of the loyalty model was subject to operationalization, taking the form of a formal model characterized by acceptable quality (Figure 5).

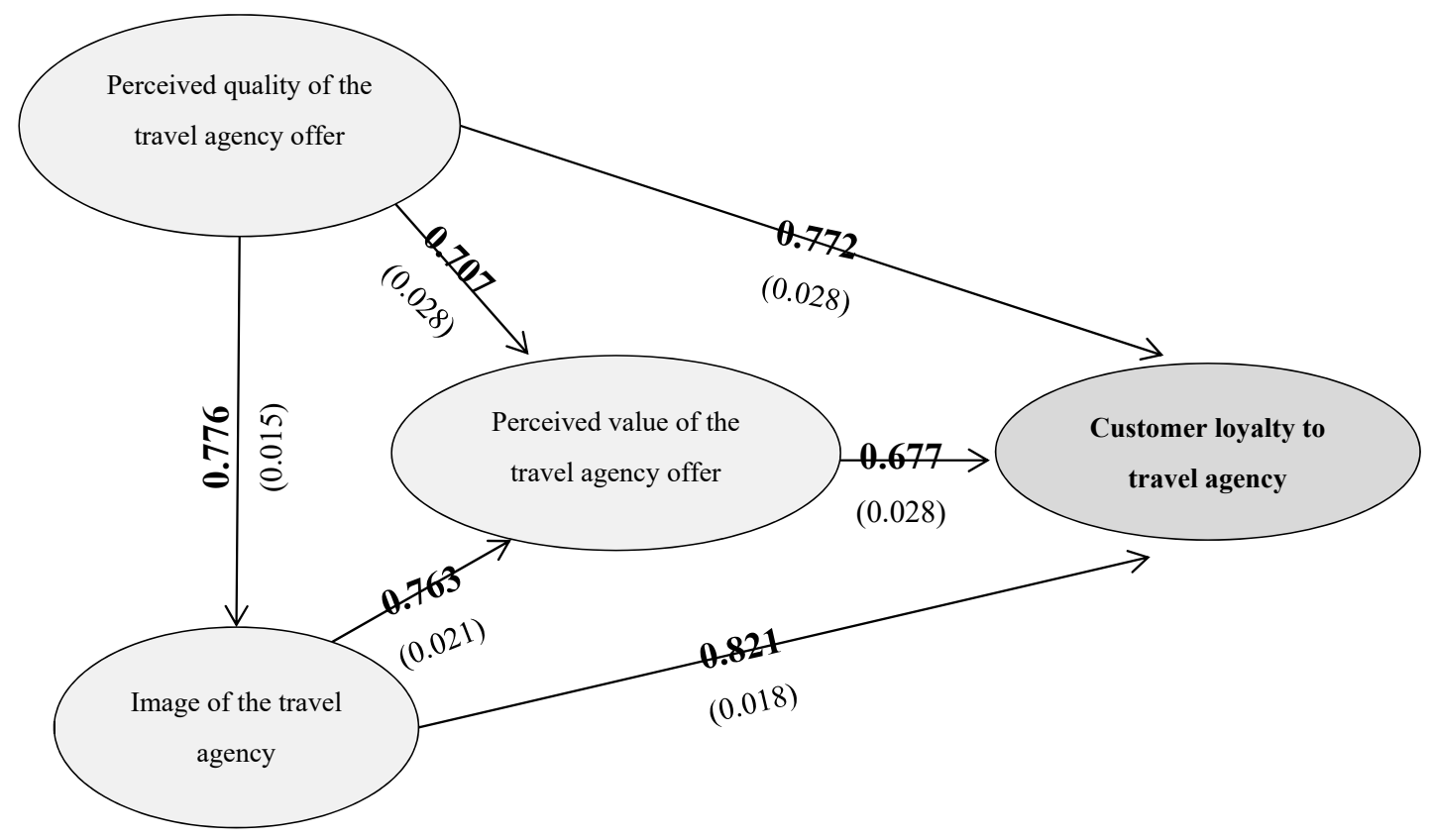

Figure 5. Formal empirical loyalty model of travel agency customers (based on survey studies and the calculation performed using the sem package of the R environment).

The arrows $(\rightarrow)$ show the direction of cause-and-effect correlations joining the identified elements; values above arrows show the estimations of equation parameters in the internal model, and those under the arrows (in brackets) present estimation errors of the equation parameter in the internal model (standard deviation). The correlations demonstrated based on empirical studies of customers of travel agency services result in a positive verification of 4 out of 7 of the proposed hypotheses. Customer loyalty depends on the perceived quality of a travel agency's offers and its image. In addition, the conducted analysis showed a positive impact of the perceived value of travel agency offers on both affective and global customer loyalty.

The presented observations confirmed that, among the format indicators, the development process of customer loyalty to travel agency services, apart from the perceived quality of the travel agency's offers and its image, is also influenced by its offer value assessment, i.e., customer critical analysis and the balance between the received benefits and the incurred costs.

The obtained results allowed us to draw the following conclusions:

- the more that customers assess the offer quality and the image of the travel agency, the more willing they are to recommend it to other people

- the higher the level of customer satisfaction with the travel agency's services, the more willing they are to return to a particular service provider and repurchases tourist services

- the higher the customers' assessments of the quality and value of travel agency's offer and their image, the greater the customer loyalty 


\subsection{Strengths and Limitations}

The strength of the developed loyalty model is ingrained in its conceptualization and operationalization. The empirical verification carried out on the basis of a non-random sample remains a weakness. As a result of applying the appropriate method of sample selection, the surveyed sample reflects the structure of the analyzed adult population in Poland.

The authors of the study are aware that developing a loyalty model using structural equation models (SEM) has its limitations. In numerous studies (see e.g., [68-74]), both weaknesses and limitations of structural equation models were identified, among which the following should be listed: errors caused by disregarding important variables, difficulties in the specification and modification of SEM models, problems in understanding the role of the null hypothesis and equivalence in SEM models, problems resulting from multicollinearity, limitations in the systematic analysis of SEM fit indices, and theoretical and philosophical controversies related to the usefulness of the SEM model.

To sum up, the presented research results provide valuable input into the existing knowledge about the phenomenon of loyalty, its measurement and the determinants of loyalty to travel agencies in Poland. This article is among the first attempts of comprehensive research in this field. Moreover, the conducted research allowed us to collect and organize knowledge about the process of developing long-term relationships between travel agencies and customers.

Author Contributions: Conceptualization, M.-D.I.; methodology, D.A., M.-D.I., W.M.; software, D.A., validation, D.A., M.-D.I., W.M.; formal analysis, M.-D.I.; investigation, J.D.E., M.-D.I.; resources, D.A., J.D.E., M.-D.I., W.M.; data curation, J.D.E., M.-D.I.; writing—original draft preparation, D.A., J.D.E., M.-D.I., W.M.; writing-review and editing, D.A., J.D.E., M.-D.I., W.M.; visualization, D.A., J.D.E., M.-D.I., W.M.; supervision, D.A., J.D.E., M.-D.I., W.M.

Funding: This research received no external funding.

Acknowledgments: We sincerely appreciate the valuable comments of anonymous reviewers and editors.

Conflicts of Interest: The authors declare no conflict of interest.

\section{References}

1. Copeland, M.T. Relation of Consumers' Buying Habits to Marketing Methods. Harv. Bus. Rev. 1923, 1, $282-289$.

2. Uncles, M.D.; Dowling, G.D.; Hammond, K. Customer Loyalty and Customer Loyalty Programs. J. Consum. Mark. 2003, 20, 294-317. [CrossRef]

3. Oliver, R.L. Whence Consumer Loyalty? J. Mark. 1999, 63, 33-44. [CrossRef]

4. Michalska-Dudek, I. Multidimensionality and Determinants of Consumer Loyalty in Tourist Services. Folia Tur. 2014, 32, 83-107.

5. Moisescu, O.I. From perceptual corporate sustainability to customer loyalty: A multi-sectorial investigation in a developing country. Econ. Res. Ekon. Istraž. 2018, 31, 55-72. [CrossRef]

6. Palacios-Florencio, B.; García del Junco, J.; Castellanos-Verdugo, M.; Rosa-Díaz, I.M. Trust as mediator of corporate social responsibility, image and loyalty in the hotel sector. J. Sustain. Tour. 2018, 26, 1273-1289. [CrossRef]

7. Martínez, P.; Rodríguez del Bosque, I. CSR and customer loyalty: The roles of trust, customer identification with the company and satisfaction. Int. J. Hosp. Manag. 2013, 35, 89-99. [CrossRef]

8. Siemieniako, D.; Urban, W. Modele lojalności klientów-Rola satysfakcji oraz kierunki badań. Mark. I Rynek 2006, 8, 12-18.

9. Urban, W.; Siemieniako, D. Lojalność Klientów. Modele, Motywacja I Pomiar; PWN: Warszawa, Poland, 2008; pp. 33-43.

10. Michalska-Dudek, I. In search for customer loyalty model of tourist services. Serv. Manag. 2015, 16, 85-95. [CrossRef]

11. Pong, L.T.; Yee, P.T. An Integrated Model of Service Loyalty. In Proceedings of the 2001 Academy of Business \& Administrative Sciences International Conferences, Brussels, Belgium, 23-25 July 2001.

12. Mc Alexander, J.H.; Kim, S.K.; Roberts, S.D. Loyalty: The Influence of Satisfaction and Brand Community Integration. J. Mark. Theory Pract. 2003, 11, 1-11. 
13. Kandampully, J.; Suhartanto, D. Customer loyalty in the hotel industry: The role of customer satisfaction and image. Int. J. Contemp. Hosp. Manag. 2000, 12, 346-351. [CrossRef]

14. Zins, A.H. Relative attitudes and commitment in customer loyalty models: Some experiences in the commercial airline industry. Int. J. Serv. Ind. Manag. 2001, 12, 269-294. [CrossRef]

15. Butcher, K.; Sparks, B.; O'Callaghan, F. Evaluative and relational influences on service loyalty. Int. J. Serv. Ind. Manag. 2001, 12, 310-327. [CrossRef]

16. Luarn, P.; Lin, H. Customer Loyalty Model for E-Service Context. J. Electron. Commer. Res. 2003, 4, $156-167$.

17. Dick, A.; Basu, K. Customer loyalty: Towards an integrated framework. J. Acad. Market. Sci. 1994, 22, 99-113. [CrossRef]

18. Johnson, M.D.; Gustafsson, A.; Andreassen, T.W.; Lerwik, L.; Cha, J. The evolution and future of national customer satisfaction index models. J. Econ. Psychol. 2001, 22, 217-245. [CrossRef]

19. Skowron, Ł. Satysfakcja i lojalność klientów jako źródło przewagi konkurencyjnej przedsiębiorstw. Zesz. Nauk. Uniw. Ekon. W Pozn. 2011, 170, 258-268.

20. Skowron, S.; Skowron, Ł. Lojalność Klienta a Rozwój Organizacji; Difin: Warszawa, Poland, 2012; p. 80.

21. Fornell, C. The ACSI Model of satisfaction. In Improving Your Measurement of Customer Satisfaction; Vavra, T.G., Ed.; American Society for Quality: Milwaukee, WI, USA, 1997; p. 25.

22. Pritchard, M.P.; Howard, D.R. The Loyal Traveler: Examining a Typology of Service Patronage. J. Travel Res. 1997, 35, 2-10. [CrossRef]

23. Petrick, J.F. An Examination of the Relationship between Golf Travelers' Satisfaction, Perceived Value, Loyalty and Intentions to Revisit. Ph.D. Thesis, Clemson University, Clemson, SA, USA, 1999.

24. Bowen, J.T.; Chen, S.-L. The Relationship between Customer Loyalty and Customer Satisfaction. Int. J. Contemp. Hosp. Manag. 2001, 13, 213-217. [CrossRef]

25. Lee, M.; Cunningham, L.F. A Cost/Benefit Approach to Understanding Service Loyalty. J. Serv. Mark. 2001, 15, 113-130. [CrossRef]

26. Petrick, J.F.; Backman, S.J. An Examination of Golf Travelers' Satisfaction, Perceived Value, Loyalty, and Intentions to Revisit. Tour. Anal. 2001, 6, 223-237.

27. Yoon, Y.; Uysal, M. An Examination of the Effects of Motivation and Satisfaction on Destination Loyalty: A Structural Model. Tour. Manag. 2005, 6, 45-56. [CrossRef]

28. Campo Martinez, S.; Yague Guillen, M.J. Effects of Price Promotions on Consumer Loyalty towards Travel Agencies. In Advanced Tourism Research Series. Progress in Tourism Marketing, 1st ed.; Kozak, M., Andreu, L., Eds.; Elsevier: Amsterdam, The Netherlands, 2006; pp. 262-279.

29. Hernández-Lobato, L.; Solis-Radilla, M.M.; Moliner-Tena, M.A.; Sánchez-García, J. Tourism Destination Image, Satisfaction and Loyalty: A Study in Ixtapa-Zihuatanejo, Mexico. Tour. Geogr. 2006, 8, 343-358. [CrossRef]

30. Kim, W.; Han, H. Determinants of Restaurant Customers' Loyalty Intentions: A Mediating Effect of Relationship Quality. J. Qual. Assur. Hosp. Tour. 2008, 9, 219-239. [CrossRef]

31. Campo, S.; Yagüe, M.J. Tourist Loyalty to Tour Operator: Effects of Price Promotions and Tourist Effort. J. Travel Res. 2008, 46, 318-326. [CrossRef]

32. Mechinda, P.; Serirat, S.; Gulid, N. An examination of tourists' attitudinal and behavioral loyalty: Comparison between domestic and international tourists. J. Vacat. Mark. 2009, 15, 129-148. [CrossRef]

33. Lee, S.; Jeon, S.; Kim, D. The impact of tour quality and tourist satisfaction on tourist loyalty: The case of Chinese tourists in Korea. Tour. Manag. 2011, 32, 1115-1124. [CrossRef]

34. Correia Loureiro, S.M.; Kastenholz, E. Corporate reputation, satisfaction, delight, and loyalty towards rural lodging units in Portugal. Int. J. Hosp. Manag. 2011, 30, 575-583. [CrossRef]

35. Seweryn, R. Kreowanie Wartości dla Klienta Przez Obszar Recepcji Turystycznej; Wydawnictwo Uniwersytetu Ekonomicznego w Krakowie: Kraków, Poland, 2012.

36. Prayag, G.; Ryan, C. Antecedents of Tourists' Loyalty to Mauritius. The Role and Influence of Destination Image, Place Attachment, Personal Involvement, and Satisfaction. J. Travel Res. 2012, 51, 342-356. [CrossRef]

37. Lai, W.-H.; Vinh, N.Q. Online Promotion and Its Influence on Destination Awareness and Loyalty in the Tourism Industry. Adv. Manag. Appl. Econ. 2013, 3, 15-30.

38. Suwunniponth, W. Tourist Satisfaction and Loyalty toward Service Quality of the Online Tourism Enterprises. Int. J. Econ. Manag. Eng. 2013, 7, 2461-2464. 
39. Haque, A.; Khan, A.H. Factors Influencing of Tourist Loyalty: A Study on Tourist Destinations in Malaysia. In Proceedings of 3rd Asia-Pacific Business Research Conference; International Islamic University: Kuala Lumpur, Malaysia, 2013; pp. 1-16.

40. Eid, R. Integrating Muslim Customer Perceived Value, Satisfaction, Loyalty and Retention in the Tourism Industry: An empirical study. Int. J. Tour. Res. 2013, 17, 249-260. [CrossRef]

41. Movafegh, A.; Movafegh, A. The Impact of Service Quality on Tourist Loyalty in Malaysian Tourism Industry. Int. J. Innov. Ideas 2013, 13, 1-19.

42. Jani, D.; Han, H. Personality, Satisfaction, Image, Ambience, and Loyalty: Testing their relationships in the hotel industry. Int. J. Hosp. Manag. 2014, 37, 11-20. [CrossRef]

43. Zong, H.; Fu, X.; Cai, L.A.; Lu, L. Destination Image and Tourist Loyalty: A meta-analysis. Tour. Manag. 2014, 40, 213-223. [CrossRef]

44. Wu, C.W. Destination loyalty modeling of the global tourism. J. Bus. Res. 2016, 69, 2213-2219. [CrossRef]

45. Akroush, M.N.; Jraisat, L.E.; Kurdieh, D.J.; AL-Faouri, R.N.; Qatu, L.T. Tourism service quality and destination loyalty-The mediating role of destination image from international tourists' perspectives. Tour. Rev. 2016, 71, 18-44. [CrossRef]

46. Akhoondnejad, A. Tourist loyalty to a local cultural event: The case of Turkmen handicrafts festiwal. Tour. Manag. 2016, 52, 468-477. [CrossRef]

47. Almeida-Santana, A.; Moreno-Gil, S. Understanding tourism loyalty: Horizontal vs. destination loyalty. Tour. Manag. 2018, 65, 245-255. [CrossRef]

48. Characteristics of Domestic and Foreign Trips of Polish Residents in 2017; Department of Tourism. Ministry of Sport and Tourism: Warsaw, Poland, 2018; p. 11. Available online: https://www.msit.gov.pl/pl/turystyka/badania-rynkuturystycz/statystyka-komunikaty-i/7855, Charakterystyka-podrozy-mieszkancow-Polski-w-2017-r.html (accessed on 23 June 2019).

49. Monthly Information on the National Economy Entities Listed in the Statistical Business Identification Register REGON, September 2018. Available online: https://stat.gov.pl/obszary-tematyczne/podmiotygospodarcze-wyniki-finansowe/zmiany-strukturalne-grup-podmiotow/miesieczna-informacja-opodmiotach-gospodarki-narodowej-w-rejestrze-regon-wrzesien-2018,4,15.html (accessed on 23 June 2019).

50. Central Register of Tourism Organizers and Entrepreneurs Facilitating Acquisition of Related Tourist Services. Available online: https://turystyka.gov.pl/ceotipt/statystyki/statystyka/1/drukuj/1/ (accessed on 24 June 2019).

51. GUS. Statistical Yearbook 2017; GUS: Warszawa, Poland, 2018.

52. Eskildsen, J.K.; Kristensen, K.; Juhl, H.J.; Østergaard, P. The Drivers of Customer Satisfaction and Loyalty: The Case of Denmark 2000-2002. Total Qual. Manag. Bus. 2004, 15, 859-868. [CrossRef]

53. Michalska-Dudek, I. Kształtowanie Lojalności Klientów Biur Podróży; Uniwersytet Ekonomiczny We Wrocławiu: Wrocław, Poland, 2017; pp. 269-285.

54. Hair, J.F., Jr.; Black, W.C.; Babin, B.J.; Anderson, R.E. Multivariate Data Analysis, 7th ed.; Pearson Prentice Hall: Upper Saddle River, NJ, USA, 2010; p. 13.

55. Bollen, K. With new incremental structural index for general equation models made. Sociol. Methods Res. 1989, 17, 303-316. [CrossRef]

56. Sagan, A. Model Pomiarowy Satysfakcji I Lojalności; StatSoft Polska: Kraków, Poland, 2003; pp. 88-89.

57. Kline, R.B. Principles and Practice of Structural Equation Modelling, 2nd ed.; Guilford Press: New York, NY, USA, 2005.

58. Kline, R.B. Principles and Practice of Structural Equation Modelling, 3rd ed.; Guilford Press: New York, NY, USA, 2011.

59. Fox, J.; Nie, Z.; Byrnes, J. sem: Structural equation Models. R package version 3.1-9. 2017. Available online: https://CRAN.R-project.org/package=sem (accessed on 24 June 2019).

60. Likert, R. A technique for the measurement of attitudes. Arch. Psychol. 1932, 22, 3-55.

61. Foxall, G.R.; Goldsmith, R.E. Psychologia konsumenta dla menedżera marketing; Polish Scientific Publishers PWN: Warsaw, Poland, 1998.

62. Albayrak, T.; Caber, M. Tourists' Satisfaction and its Interaction with Loyalty towards to a Destination. In Proceedings of the International Academy of Business Disciplines (IABD) and European Academy of Management and Business Economics (AEDEM) Conference, Salamanca, Spain, 18-20 June 2008; Salamanca University: Salamanca, Spain, 2008. 
63. Chen, Y.-S. Towards green loyalty: Driving from green perceived value, green satisfaction, and green trust. Sustain. Dev. 2013, 21, 294-308. [CrossRef]

64. Spiteri, J.M.; Dion, P.A. Customer value, overall satisfaction, end-user loyalty, and market performance in detail intensive industries. Ind. Market. Manag. 2004, 33, 675-687. [CrossRef]

65. Hallowell, R. The relationships of customer satisfaction, customer loyalty, and profitability: An empirical study. Int. J. Serv. Ind. Manag. 1996, 7, 27-42. [CrossRef]

66. Huang, L. Exploring the determinants of E-loyalty among travel agencies. Serv. Ind. J. 2008, 28, $239-254$. [CrossRef]

67. Tunalı, D.; Aytekin, A. An e-loyalty model proposal for online travel reservation websites. J. Tour. Theor. Res. 2018, 4, 98-110. [CrossRef]

68. Tomarken, A.J.; Waller, N.G. Structural Equation Modeling: Strengths, Limitations, and Misconceptions. Annu. Rev. Clin. Psychol. 2005, 1, 31-65. [CrossRef]

69. Iacobucci, D. Structural equations modeling: Fit Indices, sample size, and advanced topics. J. Consum. Psychol. 2010, 20, 90-98. [CrossRef]

70. Tarka, P. An overview of structural equation modeling: Its beginnings, historical development, usefulness and controversies in the social sciences. Qual. Quant. 2018, 52, 313-354. [CrossRef]

71. Rose, S.A.; Markman, B.; Sawilowsky, S. Limitations in the systematic analysis of structural equation model fit indices. J. Mod. Appl. Stat. Methods 2017, 16, 69-85. [CrossRef]

72. Steiger, J.H. Understanding the limitations of global fit assessment in structural equation modeling. Personal. Individ. Differ. 2007, 42, 893-898. [CrossRef]

73. Jeon, J. The Strengths and Limitations of the Statistical Modelling of Complex Social Phenomenon: Focusing on SEM, Path Analysis, or Multiple Regression Models. Int. J. Econ. Manag. Eng. 2015, 9, 1634-1642.

74. Bagozzi, R.; Yi, Y. Specification, Evaluation, and Interpretation of Structural Equation Models. J. Acad. Market. Sci. 2012, 40, 8-34. [CrossRef]

(C) 2019 by the authors. Licensee MDPI, Basel, Switzerland. This article is an open access article distributed under the terms and conditions of the Creative Commons Attribution (CC BY) license (http://creativecommons.org/licenses/by/4.0/). 